\title{
Whey protein isolate protects against cyclophosphamide-induced acute liver and kidney damage in rats
}

\author{
Dina F. Mansour ${ }^{*}$, Abeer A. A. Salama ${ }^{1}$, Rehab R. Hegazy ${ }^{1}$, Enayat A. Omara ${ }^{2}$, Somaia A. Nada ${ }^{1}$ \\ ${ }^{1}$ Pharmacology Department, Medical Division, National Research Centre, Giza, Egypt. \\ ${ }^{2}$ Pathology Department, Medical Division, National Research Centre, Giza, Egypt.
}

\section{ARTICLE INFO}

Article history:

Received on: 23/01/2017

Accepted on: 17/03/2017

Available online: 30/06/2017

Key words:

Cyclophosphamide; whey

protein isolate; oxidative

stress; inflammation; liver;

kidney; rat.

\begin{abstract}
Cyclophosphamide (CP), a common chemotherapy, interferes with the antioxidant systems of vital organs. This study investigated the protective effects of whey protein isolate (WPI) against CP-induced acute liver and kidney damage in rats. Forty adult Wistar rats were allocated into five groups. The first received the vehicles and acted as normal control. In the other groups, rats were injected with a single intraperitoneal dose of CP (200 $\mathrm{mg} / \mathrm{kg}$ ). The last three groups were pre-treated with oral WPI at doses of 75,150 or $300 \mathrm{mg} / \mathrm{kg} / \mathrm{day}$, respectively, for 15 successive days. Forty-eight hours following CP injection, animals were investigated for serum alanine transaminase, aspartate transaminase, urea and creatinine levels, as well as hepatic and renal reduced glutathione, malondialdehyde, nitrite, interleukin $1 \beta$, and myeloperoxidase contents. Histopathological examination as well as immunohistochemical detection of cyclooxygenase-2 in liver and kidney were conducted. CP induced organ dysfunction, oxidative stress, inflammation, and histopathological alterations in liver and kidney. WPI significantly protected against $\mathrm{CP}$-induced deterioration of liver and kidney functions showing marked dose-dependent anti-oxidant and anti-inflammatory properties demonstrated by the biochemical, immunohistochemical and histopathological results. In conclusion, the study reveals the protective effects of WPI against CP-induced acute liver and kidney damage via antioxidant and anti-inflammatory mechanisms.
\end{abstract}

\section{INTRODUCTION}

Cyclophosphamide (CP) is a cytotoxic alkylating agent with wide spectrum clinical uses for over 50 years and its effectiveness in the treatment of neoplastic diseases such as solid tumors and lymphomas as well as non-neoplastic diseases such as rheumatoid arthritis and systemic lupus erythematosus has been proved extensively (Lawson et al., 2008). However, multiorgan toxicity mainly in the heart, testes, and urinary bladder, hindered the clinical use of CP due to its ability to damage normal tissues (Fraiser et al., 1991). Though the metabolic activation of $\mathrm{CP}$ by hepatic microsomal cytochrome $\mathrm{P} 450$ mixed functional oxidase system is a prerequisite of $\mathrm{CP}$ therapeutic effects, toxic effects of CP like necrosis, apoptosis, and oncosis

\footnotetext{
* Corresponding Author

Dina Mansour, Ph.D., Pharmacology Department, Medical Division, National Research Centre, Bohoth st., 12622, Dokki, Giza, Egypt.

Tel: +201001350377, Email: dinaf.mansour@ gmail.com
}

are linked with two active metabolites, phosphoramide and acrolein (Ludeman, 1999; Benvegnu et al., 2010). Generation of reactive oxygen species (ROS) such as superoxide anion has be evolved during CP metabolic activation, leads to redox imbalance and oxidative stress that result in cancer and tissue damage (Abraham et al., 2011; Jnaneshwari et al., 2013). Studies reported induction of haemorrhagic cystitis, hepatic and lung damage as well as cardiotoxicity and nephrotoxicity by CP treatment (Oter et al., 2004; Cho et al., 2010; Rehman et al., 2012; Jnaneshwari et al., 2014). Owing to their nutritional and biological role upon human health, whey protein products have drawn attention in recent decades (Krissansen, 2007). Whey protein belongs to a class of protein that comprises approximately $20 \%$ of the total milk proteins (Pennings et al., 2011; Mitchell et al., 2015). It provides high levels of essential and branched chain amino acids and possesses many beneficial bioactive properties (Hoffman and Falvo, 2004). 
Whey protein concentrate has the ability to act as an antioxidant (Bounous, 2000; Pena-Ramos and Xiong, 2001), antihypertensive, antitumor (Yoo et al., 1998), hypolipidemic, antiviral (Low et al., 2003), antibacterial (Ajello et al., 2002), and chelating (Weinberg, 1996) agent. Dietary whey protein isolates (WPI) can stimulate immune system function, improve muscle strength and body composition, and inhibit cardiovascular diseases and osteoporosis (Watanabe et al., 2000). In a previous study of our team and in many studies of other research groups, the protective effects of WPI, their enzymatic digests, and peptide fractions prepared from the enzymatic digestion against different experimental animals models of hepatotoxicity and nephrotoxicity have been reported ( $\mathrm{Gad}$ et al., 2011; Athira et al., 2013; Eliwa et al., 2014; Mansour et al., 2015a). In addition, it has been found that WPI can be used as an adjuvant in cancer treatments by enhancing the cytotoxicity of anti-cancer drug (baicalein) (Tsai et al., 2000). The current study aimed to investigate the potential protective effects of WPI against some $\mathrm{CP}$-induced toxic manifestations. The study has taken in consideration that the site of metabolic degradation of CP to its toxic metabolites is the liver, and the main rout of excretion of these metabolites is through the kidney, which most likely result in the susceptibility of these two organs to a greater degree of CP-induced toxicity. Therefore, this study emphasized on the study of the acute hepatotoxicity and nephrotoxicity induced by CP in rats and the role of WPI on modulating these complications in an attempt to minimize the chemotherapeutic-associated side effects on these vital organs.

\section{MATERIAL AND METHODS}

\section{Animals}

Forty adult male Wistar rats weighing 180-200 g were utilized in the present study. Standard food pellets and tap water were supplied ad libitum. Animals and food pellets were obtained from the animal house colony of the National Research Centre (NRC, Egypt). Animals were cared for in accordance with the Guide for the Care and Use of Laboratory Animals (1996, published by National Academy Press, 2101 Constitution Ave. NW, Washington, DC 20055, USA) and that their use was reviewed and approved in accordance with ethical rules for standard experimental animal studies and the Medical Research Ethics Committee (MREC) of the NRC, and all work was conducted with the formal approval of it (number: 15020).

\section{Drugs and chemicals}

WPI was obtained from Davisco Foods International, Inc. (USA). CP (Endoxan $\left.{ }^{\circledR}\right)$ was purchased from Baxter Oncology $\mathrm{GmbH}$ (Germany). WPI was dissolved in distilled water and freshly prepared before oral administration. CP was injected intraperitoneally in a single dose of $200 \mathrm{mg} / \mathrm{kg}$ (Mahmoud, 2014; Habibi et al., 2015; Oyagbemi et al., 2016). All other chemicals were of highest analytical grade available. All mandatory laboratory health and safety procedures have been complied with in the course of conducting the experimental work in this study.

\section{Experimental design and treatment protocol}

Animals were randomly allocated into five groups (8 rats each). Rats of the 1 st group received intraperitoneal injections of saline and served as normal control group. Acute CP-toxicity was induced in the remaining 4 groups by single intraperitoneal injection of CP $(200 \mathrm{mg} / \mathrm{kg})$ on the 15 th day of treatment. Group 2 received only saline intraperitoneally for 15 days before $\mathrm{CP}$ treatment and served as CP control group. Groups 3, 4 and 5 received oral WPI $(75,150$ or $300 \mathrm{mg} / \mathrm{kg} /$ day), respectively for 15 days before CP treatment on day 15 . All animals were sacrificed $48 \mathrm{~h}$ after $\mathrm{CP}$ injection.

\section{Serum biochemical analysis}

Forty-eight hours after CP injection, rats were anaesthetized with diethyl ether and blood samples were withdrawn from the retro-orbital venous plexus. Collected blood samples were allowed to stand for $10 \mathrm{~min}$ at room temperature then centrifuged at $4{ }^{\circ} \mathrm{C}$ using cooling centrifuge (Laborezentrifugen, 2k15, Sigma, Germany) at 4000 r.p.m for 5 min. Sera were separated for assessment of levels of aspartate aminotransferase (AST) and alanine aminotransferase (ALT) using commercially available colorimetric assay kits (Biodiagnostic, Egypt) as previously described (Reitman and Frankel, 1957), in addition to serum creatinine and urea levels, using specific diagnostic kits (Biodiagnostic, Egypt).

\section{Hepatic and renal tissue biochemical analysis}

Directly after blood sampling, rats were sacrificed by cervical dislocation under ether anesthesia. Liver and kidney tissues were collected, washed in normal saline and then divided into 3 parts. The first part was homogenized using MPW-120 homogenizer (Med instruments, Poland); the homogenate was centrifuged using a cooling centrifuge (Laborezentrifugen, 2k15, Sigma, Germany) at 3000 r.p.m for $10 \mathrm{~min}$. and the supernatant was assessed for hepatic and renal levels of reduced glutathione (GSH) (Beutler et al., 1963), lipid peroxides as malondialdehyde (MDA) (Uchiyama and Mihara, 1978), and nitric oxide (NOx) metabolites (Miranda et al., 2001). Moreover, inflammatory markers such as myeloperoxidase (MPO), interleukin-1 $\beta$ (IL-1 $\beta$ ) were assessed using ELISA kits (Hycult Biotech, Netherlands) and (R\&D Systems, USA), respectively, according to the manufacturer's instructions.

\section{Immunohistochemical analysis of cyclooxygenase-2 (COX-2)}

For immunohistochemistry, $4 \mu \mathrm{m}$ thick deparaffinized liver and kidney tissue sections were used. Briefly, deparaffinized liver slices were incubated overnight with the antibodies against COX-2 diluted 1:100, Endogenous peroxidase activity was blocked by incubation in $0.075 \%$ hydrogen peroxide in PBS. For antibody detection DAKO EnVision+ System, Peroxidase/DAB kit was employed. The sections were then counterstained with hematoxylin, dehydrated using graded alcohols and xylene, and mounted with Entelan. The immunostaining intensity and cellular localization of COX-2 was analysed by light microscopy. 


\section{Histopathological examination}

The other parts of liver and kidney tissues were fixed in $10 \%$ neutral buffered formalin and embedded in paraffin wax. sections of $4 \mu \mathrm{m}$ thick were stained with Hematoxylin and Eosin (H\&E) and examined using binocular Olympus CX31 microscope (Bancroft et al., 1996).

\section{Statistical analysis}

All values are presented as means \pm standard error of the means (SEM) of eight experiments. Comparisons between different groups were carried out using one way analysis of variance (ANOVA) followed by Tukey's multiple comparison post hoc test. Difference was considered significant when $p<0.05$. GraphPad prism ${ }^{\circledR}$ software version 6 for Windows (USA) was used to carry out these statistical tests.

\section{RESULTS AND DISCUSSION}

Administration of single intraperitoneal dose of CP (200 $\mathrm{mg} / \mathrm{kg}$ ) resulted in a significant elevation of liver and kidney function biomarkers. Liver function enzymes, ALT and AST, were elevated significantly in CP-treated rats by 51 and $85 \%$, respectively, compared to their normal counterparts. Meanwhile, $\mathrm{CP}$ increased the levels of serum creatinine and urea significantly by 77 and $85 \%$, respectively, compared to the normal group.
Pre-treatment of rats with oral WPI at 75,150 or 300 $\mathrm{mg} / \mathrm{kg} /$ day, significantly improved both liver and kidney functions in a dose-dependent manner as compared to $\mathrm{CP}$-treated rats, to report normal levels of AST, creatinine, and urea in rats pretreated with $300 \mathrm{mg} / \mathrm{kg}$ of WPI (Table 1). CP (200 mg/kg, i.p.) resulted in liver damage in rats as evidenced by the marked decrease in hepatic GSH, with significant increase in MDA, NOx, MPO, and IL-1 $\beta$ contents as compared to the normal control group. Pre-treatment of rats with WPI $(75,150$ or $300 \mathrm{mg} / \mathrm{kg})$ significantly elevated the decreased liver GSH in a dose-dependent manner compared to the CP-control group. On the other hand, oral WPI at 75,150 and $300 \mathrm{mg} / \mathrm{kg}$, for 15 days prior CP injection significantly reduced the elevation in hepatic MDA, NOx, MPO and IL- $1 \beta$ compared to the CP-control group. Of note, WPI at 300 $\mathrm{mg} / \mathrm{kg}$ recorded significant decrease of MDA, NO, MPO and IL$1 \beta$ compared to the other dose levels of WPI (Table 2 ).

Single intraperitoneal injection of CP, $200 \mathrm{mg} / \mathrm{kg}$, resulted in severe kidney damage in rats as evidenced by significant decrease in renal GSH by $42 \%$, along with significant dramatic increase in renal MDA, NOx, MPO and IL- $1 \beta$ content by $1.7,1.9,12$, and 6-fold, respectively, as compared to the normal control group. Pre-treatment of rats with WPI, at 75, 150 and 300 $\mathrm{mg} / \mathrm{kg}$, significantly elevated renal GSH while decreased renal MDA, NOx, MPO and IL-1 $\beta$ in a dose dependent manner compared to the CP-control group (Table 3).

Table 1: Effect of WPI on liver and kidney functions of CP-treated rats.

\begin{tabular}{|c|c|c|c|c|}
\hline Parameters & ALT (IU/L) & AST (IU/L) & Creatinine (mg/dl) & Urea $(\mathrm{mg} / \mathrm{dl})$ \\
\hline \multicolumn{5}{|l|}{ Groups } \\
\hline Normal control & $123.83^{b} \pm 3.20$ & $137.58^{\mathrm{b}} \pm 2.15$ & $4.69^{b} \pm 0.33$ & $26.48^{\mathrm{b}} \pm 0.74$ \\
\hline $\mathrm{CP}(200 \mathrm{mg} / \mathrm{kg})$ & $187.12^{\mathrm{a}} \pm 1.98$ & $254.82^{\mathrm{a}} \pm 7.30$ & $8.30^{\mathrm{a}} \pm 0.19$ & $48.89^{\mathrm{a}} \pm 2.20$ \\
\hline WPI $(75 \mathrm{mg} / \mathrm{kg})+\mathrm{CP}$ & $167.59^{\mathrm{ab}} \pm 2.03$ & $234.45^{\mathrm{ab}} \pm 3.90$ & $6.00^{\mathrm{ab}} \pm 0.18$ & $41.62^{\mathrm{ab}} \pm 1.19$ \\
\hline WPI $(150 \mathrm{mg} / \mathrm{kg})+\mathrm{CP}$ & $151.01^{\mathrm{abc}} \pm 2.04$ & $176.01^{\mathrm{abc}} \pm 3.20$ & $5.24^{\mathrm{b}} \pm 0.22$ & $38.91^{\mathrm{ab}} \pm 0.16$ \\
\hline WPI (300 mg/kg)+CP & $145.94^{\mathrm{abc}} \pm 4.92$ & $153.66^{\text {bcd }} \pm 5.80$ & $4.68^{b c} \pm 0.09$ & $31.43^{\text {bcd }} \pm 0.41$ \\
\hline
\end{tabular}

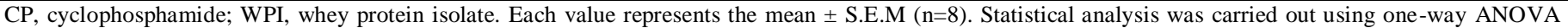

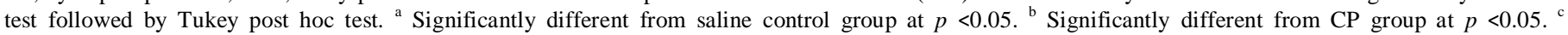
Significantly different from WPI $(75 \mathrm{mg} / \mathrm{kg})$ group at $p<0.05$. ${ }^{\mathrm{d}}$ Significantly different from WPI $(150 \mathrm{mg} / \mathrm{kg}) \mathrm{group}$ at $p<0.05$.

Table 2: Effects of WPI on hepatic contents of GSH, MDA, NOx, MPO, and IL-1 $\beta$ in CP-treated rats.

\begin{tabular}{|c|c|c|c|c|c|}
\hline $\begin{array}{ll}\text { Groups } & \text { Parameters } \\
\end{array}$ & $\begin{array}{c}\text { GSH } \\
(\mu \mathrm{mol} / \mathrm{g})\end{array}$ & $\begin{array}{c}\text { MDA } \\
(\mathrm{nmol} / \mathrm{g})\end{array}$ & $\begin{array}{c}\text { NOx } \\
(\mathrm{nmol} / \mathrm{gl})\end{array}$ & $\begin{array}{r}\text { MPO } \\
(\mathrm{U} / \mathrm{g})\end{array}$ & $\begin{array}{l}\text { IL-1及 } \\
(\mathrm{pg} / \mathrm{g})\end{array}$ \\
\hline Normal Control & $396.57^{b} \pm 9.21$ & $56.50^{\mathrm{b}} \pm 0.43$ & $396.40^{\mathrm{b}} \pm 10.30$ & $1.14^{\mathrm{b}} \pm 0.03$ & $6.55^{b} \pm 0.16$ \\
\hline $\mathrm{CP}(200 \mathrm{mg} / \mathrm{kg})$ & $293.86^{\mathrm{a}} \pm 6.00$ & $72.5^{\mathrm{a}} \pm 1.04$ & $727.02^{\mathrm{a}} \pm 21.40$ & $10.70^{\mathrm{a}} \pm 0.23$ & $45.85^{\mathrm{a}} \pm 1.43$ \\
\hline WPI $(75 \mathrm{mg} / \mathrm{kg})+\mathrm{CP}$ & $306.35^{\mathrm{ab}} \pm 8.63$ & $52.12^{\mathrm{b}} \pm 1.64$ & $630.64^{\mathrm{ab}} \pm 15.03$ & $6.60^{\mathrm{ab}} \pm 0.23$ & $27.30^{\mathrm{ab}} \pm 0.40$ \\
\hline WPI $(150 \mathrm{mg} / \mathrm{kg})+\mathrm{CP}$ & $335.72^{\mathrm{abc}} \pm 5.78$ & $58.40^{\mathrm{bc}} \pm 1.60$ & $623.40^{\mathrm{ab}} \pm 10.80$ & $4.20^{\mathrm{abc}} \pm 0.07$ & $18.50^{\mathrm{abc}} \pm 0.34$ \\
\hline WPI $(300 \mathrm{mg} / \mathrm{kg})+\mathrm{CP}$ & $361.36^{\mathrm{abcd}} \pm 4.46$ & $50.64^{\mathrm{bd}} \pm 1.20$ & $610.43^{\mathrm{ab}} \pm 11.08$ & $2.33^{\mathrm{abcd}} \pm 0.08$ & $11.84^{\mathrm{abcd}} \pm 0.24$ \\
\hline
\end{tabular}

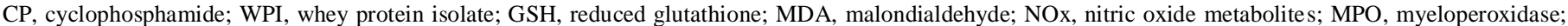

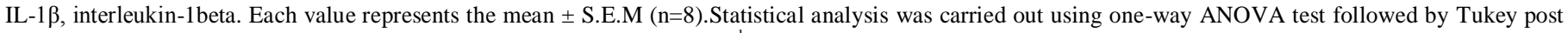

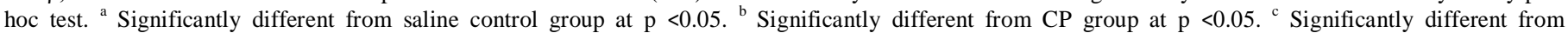
WPI $(75 \mathrm{mg} / \mathrm{kg})$ group at $\mathrm{p}<0.05 .{ }^{\mathrm{d}}$ Significantly different from WPI $(150 \mathrm{mg} / \mathrm{kg})$ group at $p<0.05$.

Table 3: Effects of WPI on renal contents of GSH, MDA, NOx, MPO, and IL-1 $\beta$ in CP-treated rats.

\begin{tabular}{|c|c|c|c|c|c|}
\hline $\begin{array}{ll}\text { Groups } & \text { Parameters } \\
\end{array}$ & $\begin{array}{c}\text { GSH } \\
(\mu \mathrm{mol} / \mathrm{g})\end{array}$ & $\begin{array}{c}\text { MDA } \\
(\mathrm{nmol} / \mathrm{g})\end{array}$ & $\begin{array}{c}\text { NO } \\
(\mu \mathrm{mol} / \mathrm{gl})\end{array}$ & $\begin{array}{l}\text { MPO } \\
(\mathbf{U} / g)\end{array}$ & 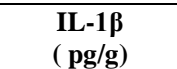 \\
\hline Normal control & $225.70^{b} \pm 2.32$ & $71.00^{\mathrm{b}} \pm 1.15$ & $299.15^{b} \pm 2.27$ & $0.66^{b} \pm 0.02$ & $4.45^{\mathrm{b}} \pm 0.16$ \\
\hline $\mathrm{CP}(200 \mathrm{mg} / \mathrm{kg})$ & $130.57^{\mathrm{a}} \pm 1.71$ & $121.87^{\mathrm{a}} \pm 3.10$ & $580.85^{\mathrm{a}} \pm 6.50$ & $8.52^{\mathrm{a}} \pm 0.25$ & $29.31^{\mathrm{a}} \pm 0.60$ \\
\hline WPI $(75 \mathrm{mg} / \mathrm{kg})+\mathrm{CP}$ & $197.93^{\mathrm{ab}} \pm 1.74$ & $90.64^{b} \pm 2.03$ & $444.70^{\mathrm{ab}} \pm 8.90$ & $4.45^{\mathrm{ab}} \pm 0.20$ & $20.20^{\mathrm{ab}} \pm 0.36$ \\
\hline WPI $(150 \mathrm{mg} / \mathrm{kg})+\mathrm{CP}$ & $199.80^{\mathrm{ab}} \pm 10.58$ & $87.87^{\mathrm{ab}} \pm 2.09$ & $404.90^{\mathrm{abc}} \pm 7.21$ & $2.31^{\mathrm{abc}} \pm 0.08$ & $13.67^{\mathrm{abc}} \pm 0.35$ \\
\hline WPI $(300 \mathrm{mg} / \mathrm{kg})+\mathrm{CP}$ & $216.14^{\mathrm{b}} \pm 4.23$ & $82.36^{\mathrm{abc}} \pm 0.80$ & $308.72^{\text {bcd }} \pm 6.90$ & $1.71^{\mathrm{abc}} \pm 0.05$ & $9.73^{\mathrm{abcd}} \pm 0.20$ \\
\hline
\end{tabular}

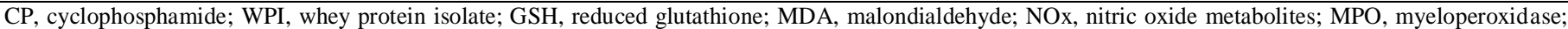

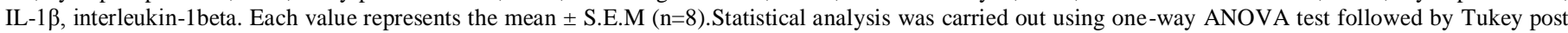

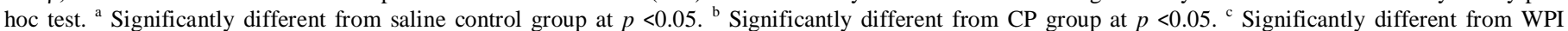
$(75 \mathrm{mg} / \mathrm{kg})$ group at $p<0.05 .{ }^{\mathrm{d}}$ Significantly different from WPI $(150 \mathrm{mg} / \mathrm{kg})$ group at $p<0.05$. 
Regarding immunohistochemical examination of COX-2 in liver and kidney tissues; immunohistochemical analysis revealed non-detectable level of COX-2 expression in the livers from normal control group (Fig. 1A). CP injection caused marked increases in the immunoreactivity of COX-2 in the cytoplasm of hepatocytes as compared to the control group (Fig. 1 B). WPI-pretreated groups revealed weak expression of COX-2 at WPI (75 $\mathrm{mg} / \mathrm{kg}$ ) dose level (Fig. 1 C). While, WPI at 150 and $300 \mathrm{mg} / \mathrm{kg}$, attenuated the formation of COX-2 in the livers, in a dosedependent manner (Fig. 1 D and E).

Renal immunohistochemical examination showed negative immunoreactivity of COX-2 expression in the glomeruli and tubules of kidney from normal control group (Fig. 2A). Rats treated with $\mathrm{CP}$ showed elevated immunoreactivity of COX-2 in the glomeruli and tubules of kidney (Fig. 2 B). However, WPItreated rats showed reduction in the expression COX-2 in the glomeruli and tubules of kidney in a dose-dependent manner (Fig. $2 \mathrm{C}, \mathrm{D}$, and $\mathrm{E}$ ).

Concerning histopathological examination of liver and kidney tissues; liver sections of normal control rat exhibited normal hepatic cells each with well-defined cytoplasm, prominent nucleus, nucleolus, central vein and blood sinusoids (Fig. 3 A). Forty-eight hours after CP intoxication, liver tissues showed loss of hepatic architecture with centrilobular hepatic necrosis, degeneration of hepatocytes, vacuolization, and congestion of sinusoids and infiltration of mononuclear cells especially near the portal veins. Also, nuclei of most cells revealed clear signs of pyknosis and apoptosis with activation of kupffer cell (Fig.3 B).

Treatment with WPI (75 mg/kg. p.o) for 15 days prior to CP exerted moderate improvement. Hepatic cords were slightly distorted, necrosis some hepatocytes, congestion and dilation of sinusoids. In addition, nuclei of some cells were pyknosis, apoptosis with activation of kupffer cell (Fig.3C). However, treatment with WPI $(150 \mathrm{mg} / \mathrm{kg}$. p.o) showed improvement in histological structure of liver sections of rats, pronounced in normalized appearance of liver in the formation of normal hepatic cords. Pyknotic nuclei and activation of kupffer cell were also observed (Fig.3 D). Meanwhile, WPI (300 mg/kg. p.o)-treated group showed improvement in hepatic architecture and central vein slightly dilated, with persistent few pyknotic nuclei, activation of kupffer cell with mild congestion in some of the sinusoids (Fig. 3E).

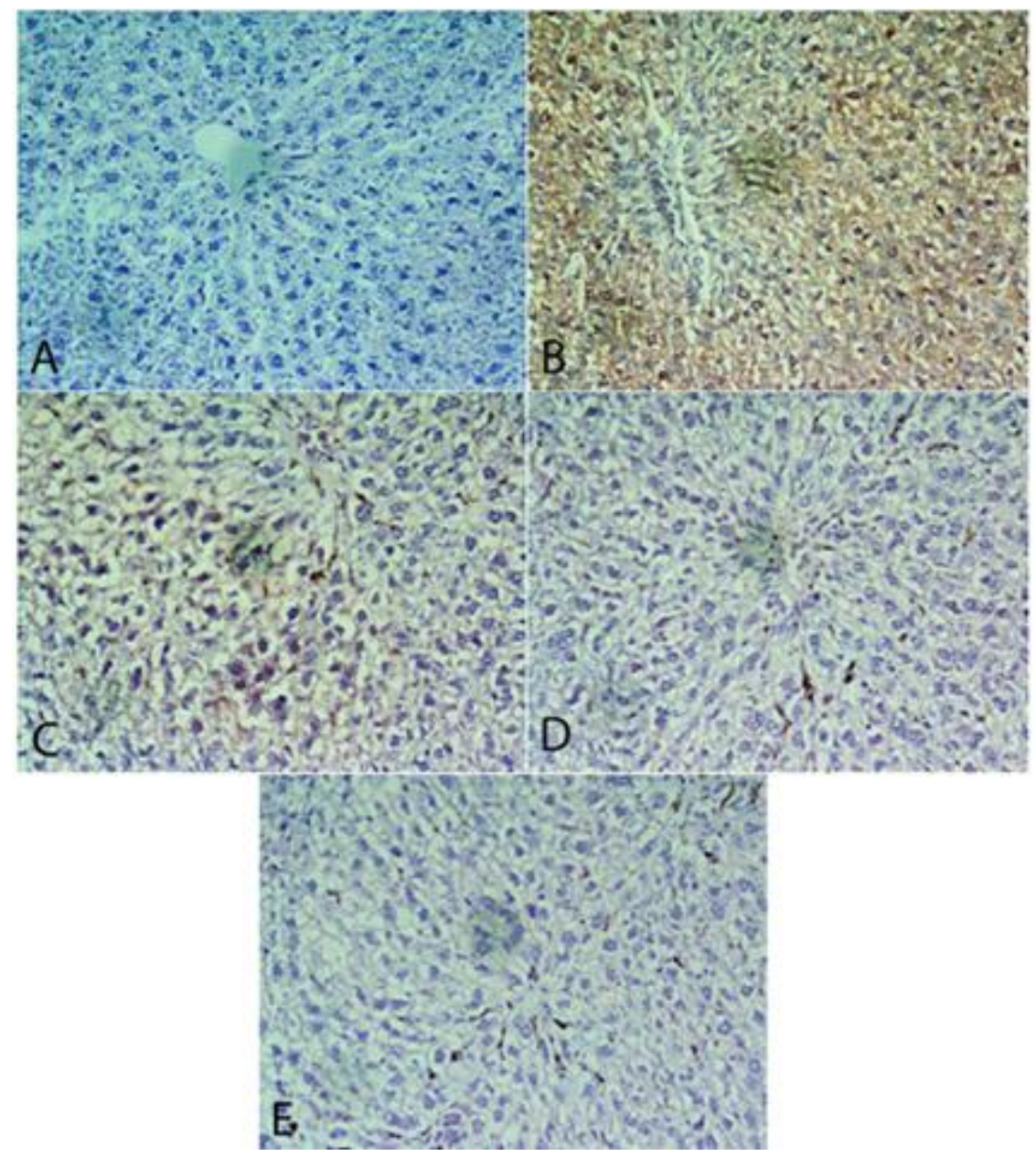

Fig. 1: Effect of WPI on immunohistochemical staining of COX-2 of CP-treated liver tissue in rats.

$\mathrm{CP}$, cyclophosphamide; WPI, whey protein isolate; COX-2, cyclooxygenase-2. A. Control group showing no expression of COX-2. B. Cyclophosphamide group showing marked increase of COX-2 immunoreactivity. C. WPI $(75 \mathrm{mg} / \mathrm{kg}$. p.o) showing mild immunoreactivity of COX-2. D. WPI (150 mg/kg. p.o) showing weak immunoreactivity of COX-2. E. WPI (300 mg/kg. p.o) showing weak immunoreactivity of COX-2 (COX-2 and hematoxylin counterstain X 400). 

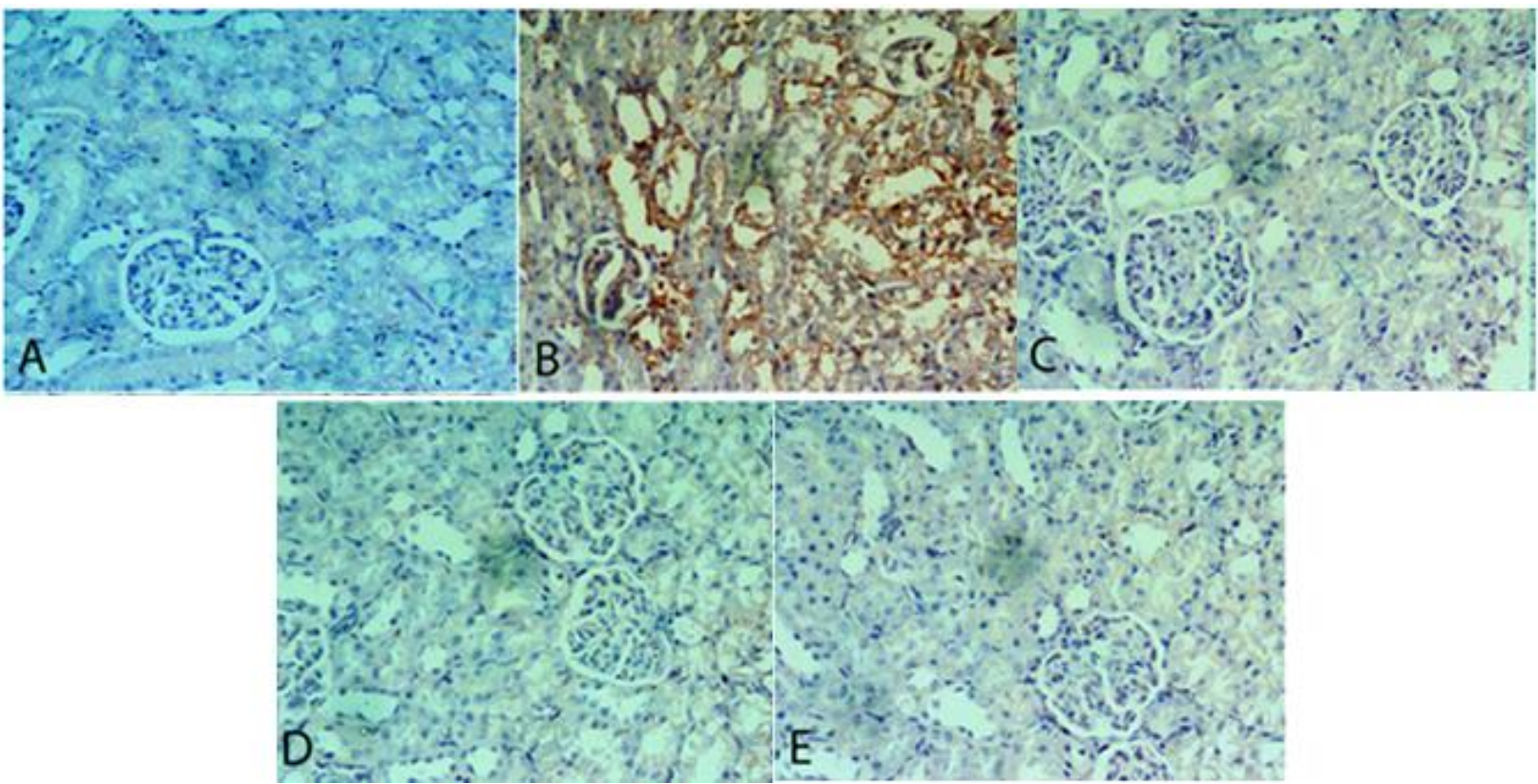

Fig. 2: Effect of WPI on immunohistochemical staining of COX-2 of CP-treated kidney tissue in rats.

$\mathrm{CP}$, cyclophosphamide; WPI, whey protein isolate; COX-2, cyclooxygenase-2. A. Control group showing no expression of COX-2(A). B. Cyclophosphamide group showing increase of COX-2. C. WPI (75 mg/kg. p.o) showing mild immunoreactivity of COX-2. D. WPI (150 mg/kg. p.o) showing of weak immunoreactivity of COX-2. E. WPI (300 mg/kg. p.o) showing of weak immunoreactivity of COX-2. (COX-2 and hematoxylin counterstain X 400).
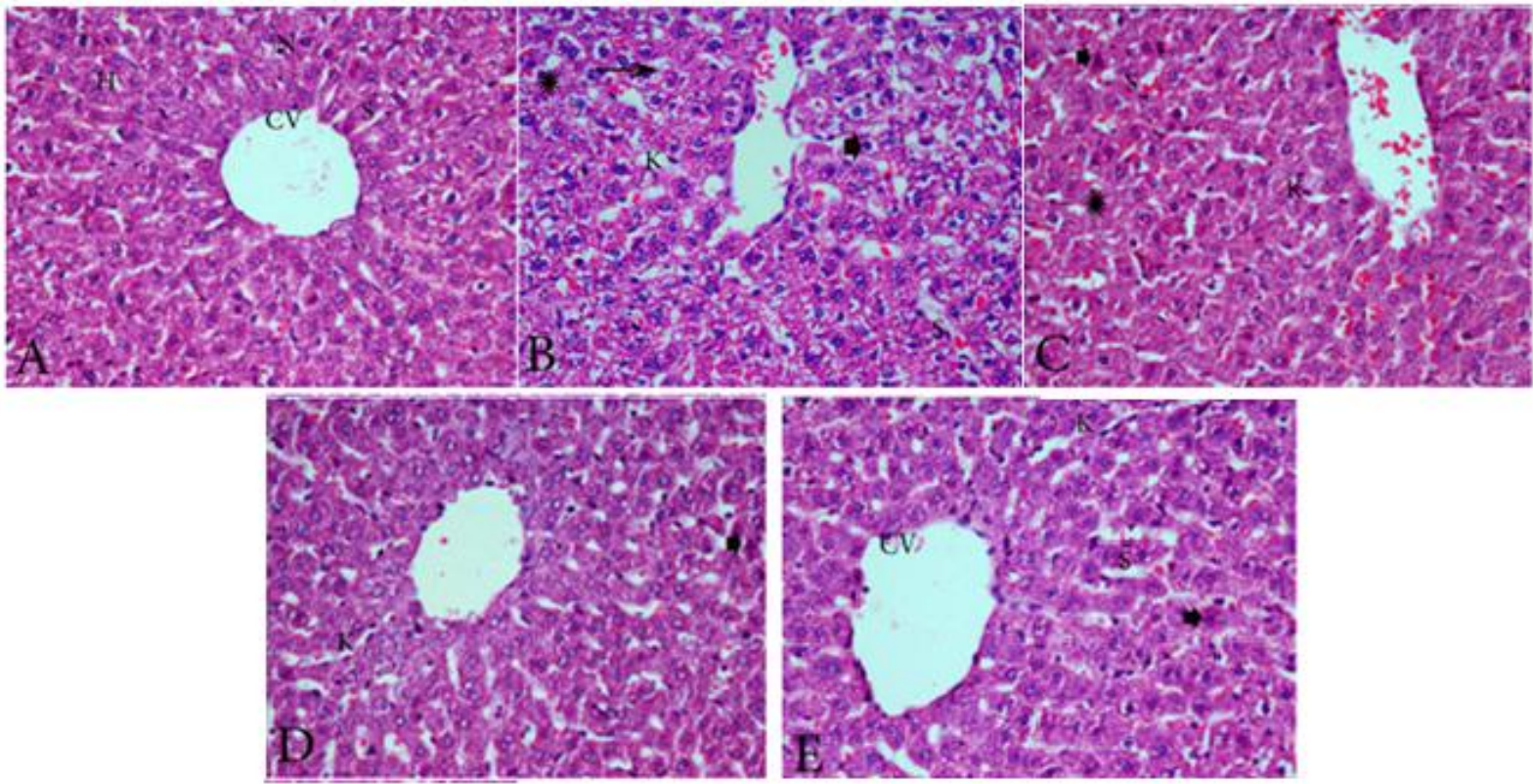

Fig. 3: Effect of WPI on hepatic architecture of CP-treated liver tissue in rats.

CP, cyclophosphamide; WPI, whey protein isolate. A. Normal liver section showing central vein (CV) normal hepatocytes $(\mathrm{H})$, nucleus $(\mathrm{N})$ and blood sinusoids (S). B. Cyclophosphamide treated liver showing loss of hepatic architecture with centrilobular hepatic necrosis (star), degeneration of hepatocytes (thin arrow), and congestion of sinusoids (S). Nuclei of most cells revealed clear signs of pyknosis (head arrow) with activation of kupffer cells (K). C. Whey protein isolate (75 mg/kg. p.o) showing moderate improvement, hepatic cords were slightly distorted, necrosis of some hepatocytes (star), congestion and dilation of sinusoids (S). Nuclei of some cells showed pyknosis (arrow head) with activation of kupffer cell (K). D. Whey protein isolate (150 mg/kg. p.o) showing improvement in histological structure of liver sections of rats and normal hepatic pyknotic nuclei (arrow head) and activation of kupffer cell (K) were also observed. E. Whey protein isolate $(300 \mathrm{mg} / \mathrm{kg}$. p.o) showing improvement in hepatic architecture and central vein slightly dilated. Few pykn otic nuclei (arrow head), activation of kupffer cell (K) mild congestion in some of the sinusoids (S) were also noticed. (H\&E X 400). 


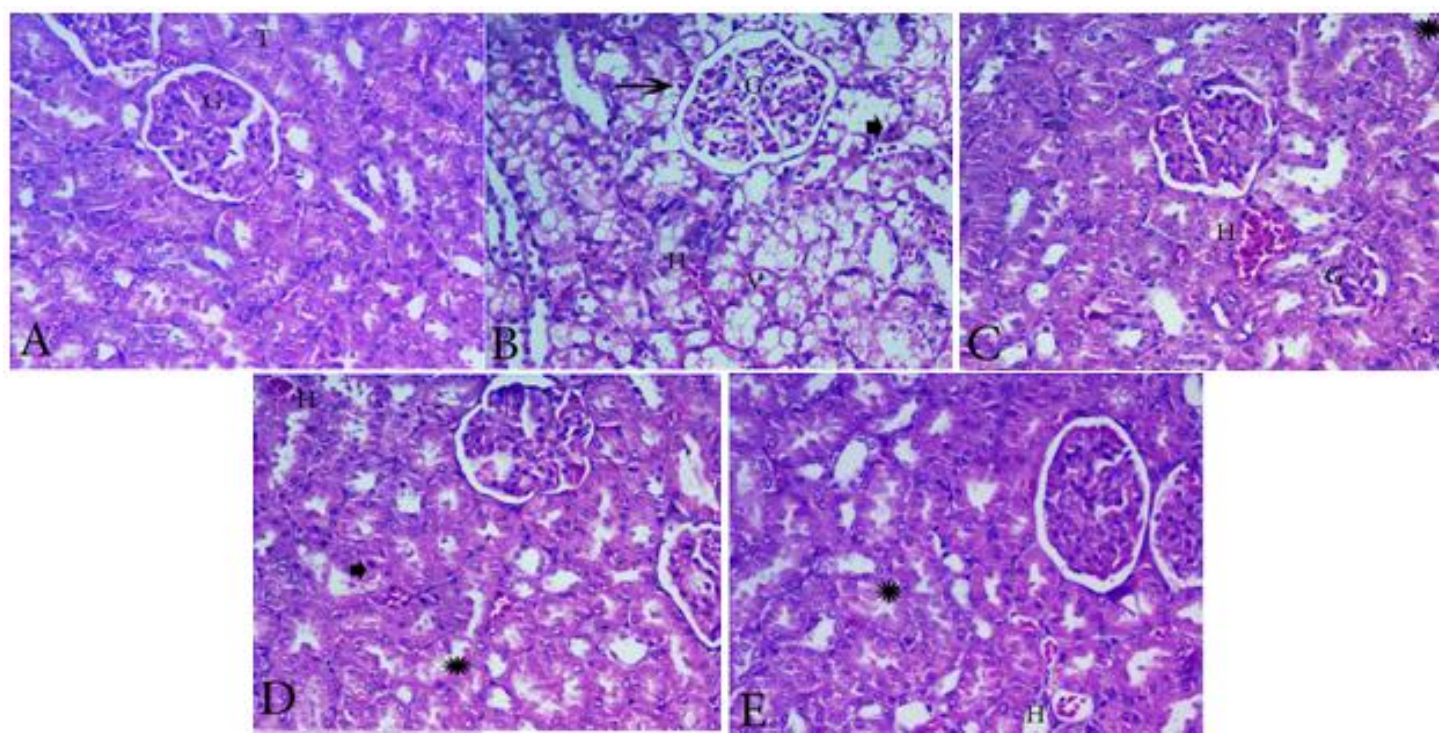

Fig. 4: Effect of WPI on renal architecture of CP-treated liver tissue in rats.

CP, cyclophosphamide; WPI, whey protein isolate. A. Normal kidney section showing normal histological features of glomeruli and tubules. B.

Cyclophosphamide treated kidney showing glomerular degeneration $(\mathrm{G})$, and hypercellularity. Most of the cortical tubules showed morphologic changes, some of them being tubular necrosis, degeneration, vacuolation $(\mathrm{V})$ and desquamation of tubular epithelium with interstitial hemorrhage (H). Also, nuclei of most cells revealed clear signs of pyknosis (arrow head) and apoptosis (thin arrow). C. Whey protein isolate $(75 \mathrm{mg} / \mathrm{kg}$. p.o) showing mild improvement, however some glomeruli were degenerated $(\mathrm{G})$. Also, some tubules still necrosis (star) with interstitial hemorrhage $(\mathrm{H})$. D. Whey protein isolate $(150 \mathrm{mg} / \mathrm{kg}$. p.o) showing more remarkable improvement and the glomeruli were normal. The kidney tubules showed necrosis, pyknotic nuclei (arrow head) with interstitial hemorrhage (H).E. Whey protein isolate $(300 \mathrm{mg} / \mathrm{kg}$. p.o) showing more remarkable improvement and the glomeruli were normal. The kidney tubules showed necrosis (star) with interstitial hemorrhage (H). (H\&E X 400).

Kidney sections of normal control rat showed apparently normal histological features of glomeruli and tubules (Fig. 4A). Histopathological examination revealed that $\mathrm{CP}$ induced severe lesions in rat kidneys, evidenced by glomerular degeneration, hypercellularity and shrinkage. Most of the cortical tubules showed morphologic changes, some of them being tubular necrosis, degeneration, vacuolation and desquamation of tubular epithelium with interstitial haemorrhage. Also, nuclei of most cells revealed clear signs of pyknosis and apoptosis (Fig. 4B). Oral treatment with WPI $(75 \mathrm{mg} / \mathrm{kg}$. p.o) showed mild improvement, however some glomeruli were degenerated and some tubular necrosis with interstitial haemorrhage were evident (Fig. 4C). Treatment with WPI (150 and $300 \mathrm{mg} / \mathrm{kg}$. p.o) showed a more remarkable improvement and the glomeruli were normal, while renal tubules showed mild necrosis with interstitial haemorrhage (Fig. 4D and E).

The present study demonstrated induction of acute hepatic and renal damage in rats following 48-hours of single intraperitoneal dose of CP $(200 \mathrm{mg} / \mathrm{kg})$. Our data revealed increased serum activities of ALT and AST in those rats along with high serum levels of creatinine and urea reflecting both hepatotoxicity and renal toxicity. Similar hepatotoxic effect and alteration of liver functions biochemical parameters by $\mathrm{CP}$ have been documented by other research groups (Zarei and Shivanandappa, 2013; Germoush and Mahmoud, 2014; Zhu et al., 2015). In addition, CP-induced renal toxicity with elevation in serum creatinine and urea has been recognized (Sayed-Ahmed, 2010; Rehman et al., 2012; Alhumaidha et al., 2015). More importantly, CP has been found to cause clinically self-limiting uroepithelial and renal tubular damage due to accumulation of acrolein, the toxic metabolite, in the urine at high concentrations (Hamsa and Kuttan, 2011).

A reversal of CP-induced increased serum ALT, AST, creatinine, and urea in rats was observed with WPI supplementation in a dose-dependent fashion. This indicated protective properties of WPI that resulted in a prevention of the leakage of intracellular enzymes from hepatocytes and restoration of normal renal functions. The hepatoprotective properties of WPI have been proved in several animal models of hepatotoxicity (Gad et al., 2011; Mansour et al., 2013; Salama et al., 2015). On the other hand, debate has raised about the effect of using whey protein in the kidney functions. Consumption of high-wheyprotein diets was found to cause alterations in renal health status and some metabolic parameters in rats (Aparicio et al., 2011). However, at the centre of this controversy is the concern that the potential induction of renal problems arises from habitual consumption of dietary whey protein in excess of recommended amounts. Interestingly, evidences suggest that protein-induced changes in renal function are likely a normal adaptive mechanism within the functional limits of a healthy kidney (Martin et al., 2005). However, the hepato- and renoprotective effects of WPI were confirmed in this study by the improvement of CP-induced oxidative, inflammatory, and histopathological alterations in both liver and kidneys. In addition to its pro-oxidant nature and its ability to elicit oxidative injury (Selvakumar $e t$ al., 2005), CP and its metabolites induced depletion of GSH that may be attributed to direct conjugation of $\mathrm{CP}$ and its metabolites with free or protein bound -SH group (Kehrer and Biswal, 2000). In agreement, CP in 
our study resulted in a significant decrease of both hepatic and renal GSH along with an increase in hepatic and renal MDA as an indicator of involvement of free radical-induced lipid peroxidation in both organs (Collins et al., 1994). Herein, depletion of GSH seems to be a prime factor that permits lipid peroxidation in the CP-treated group. Moreover, our data revealed increased levels of NOx in liver and kidneys of CP-treated rats; this could be attributed to acrolein ability to activate both ROS and NO production with further production of superoxide anion, hydroxyl radical and hydrogen peroxide during $\mathrm{CP}$ oxidative metabolism leading to depressed antioxidant defence mechanism in different tissues (Senthilkumar et al., 2006; Abraham et al., 2011). Moreover, superoxide radical may react with NO producing peroxynitrite, which may impair various mitochondrial enzymes leading to more sustained intracellular ROS generation, resulting in an augmentation of oxidative/nitrosative stress (Lipton et al., 1993).

The present study reported significant modulation of CPprompted oxidative/nitrosative stress in liver and kidney by WPI supplementation in a dose dependent-manner. Noteworthy, WPI (300 mg/kg) normalized hepatic MDA as well as renal GSH and NOx contents. Several reports indicated that WPI has potential antioxidant activity due to its ability to elevate cellular GSH levels (Tseng et al., 2006; Peng et al., 2009). Most whey proteins are cysteine rich, including $\alpha$-lactalbumin, $\beta$-lactoglobulin, and bovine serum albumin (Morr and Ha, 1993). Cysteine is known as an amino acid that regulates in vivo concentrations of GSH. The supplementation of diet with whey protein high in cysteine may promote GSH biosynthesis. The latter has been reported to be an antioxidant and anticarcinogenic tripeptide, thus improving protection against oxidant-induced cell damage (Bounous et al., 1989). The elevated levels of GSH reported in the present study after treatment with WPI along with decreased levels of MDA and NOx supported previous findings and recent reports of our team that stated potent antioxidant activity of WPI at different dose levels that replenished the antioxidant pool, enzymatic and nonenzymatic, while abolished lipid peroxidation and nitrosative stress in different models of hepatotoxicity (Mansour et al., 2013; Mansour et al., 2015a; Salama et al., 2015). Further, major components of whey protein have been investigated for their protective mechanisms against liver and brain damage (Mansour et al., 2015b) as well as liver fibrosis incidence by thioacetamide (Nada et al., 2015).

In addition to oxidative and nitrosative stress insult, the present study reported that CP-exacerbated liver and kidney injury was further mediated via an inflammatory process including dramatic rise in levels of hepatic and renal MPO, a marker of neutrophil infiltration (Linares-Fernandez and Alfieri, 2007; Abraham et al., 2011), together with high level of IL-1 $\beta$, a proinflammatory cytokine, and COX-2 expression in rat liver and kidney. In the same context, previous studies of our team and others reported inflammatory changes induced by CP in different organs through elevation of IL-1 $\beta$, inducible NO synthase, and COX-2 activities, and revealed a cross talk between NO and COX-
1/COX-2 isoforms (Linares-Fernandez and Alfieri, 2007; Saleh and Mansour, 2016). Consistently, the current data showed that $\mathrm{CP}$-induced increase in the levels of inflammatory mediators and COX-2 expression in hepatic and renal tissues was accompanied by an increase in NOx level. Similarly, an established relation between IL-1 $\beta$ and COX-2 in CP-induced cystitis has been reported (Girard et al., 2008) through several lines of evidence that further suggest that IL-1 $\beta$ may cause hyperalgesia by releasing COX products through stimulation of COX-2 (Geng et al., 1995; Samad et al., 2001) and phospholipase A2 (Girard et al., 2008) or by inducing arachidonic acid release (Dinarello, 1997).

Treatment of rats with WPI hampered CP-induced inflammation as pronounced by the decrease in MPO activity, IL$1 \beta$ level, and COX-2 expression in hepatic and renal tissues. As stated before, WPI has a potent GSH-boosting and antioxidant activity that may correlate to its anti-inflammatory effect observed above, depending on the fact that the synthesis of many cytokines is affected by the oxidant/antioxidant balance (Kent et al., 2003). The anti-inflammatory properties of WPI together with its major components, $\alpha$-lactalbumin and $\beta$-lactoglobulin have been reported before (Mansour et al., 2015a). Moreover, lactoferrin, the minor component of WPI, was found to possess anti-inflammatory activities through inhibition of cytokine production such as IL-1 $\beta$, TNF- $\alpha$ and IL-6 from lipopolysaccharide-sensitized kupffer cells (Yamaguchi et al., 2001). Interestingly, recent studies reported hepato- and renoprotective effects of lactoferrin in rats through inhibition of inflammation and reduction of inflammatory markers such as TNF- $\alpha$, IL-18, and IL-4 (Hessin et al., 2015; Hegazy et al., 2016).

The histopathological findings in the present study confirmed the biochemical and immunohistochemical data. Investigations of hepatic and renal tissues of animals treated with $\mathrm{CP}$ exposed a marked distortion in the architecture of the liver and kidney. In the liver, the cellular targets of $\mathrm{CP}$ in rat liver were found to be related to $\mathrm{CP}$ metabolites that cause death of sinusoidal endothelial cells that are more susceptible to $\mathrm{CP}$ toxicity than hepatocytes with profound depletion of GSH before the onset of toxicity (DeLeve, 1996). Meanwhile, numerous data confirmed that $\mathrm{CP}$-induced hepatotoxicity was associated with, at least in part, the level of GSH, which played an important role in eliminating active metabolites and defending the oxidative stress in vivo (Lu, 2009).

This explanation may provide further confirmation of the potential mechanism through which WPI improved the histopathologic picture of CP-treated rat liver in a dose-dependent fashion in the present study through its GSH-boosting and antioxidant properties.

Acute renal toxicity by $\mathrm{CP}$ was also confirmed by histopathological changes in kidney including severe tubular necrosis, oedema, haemorrhage, degeneration, tubular dilatation, and glomerular degeneration. Acute tubular necrosis, azotemia, glomerular mesangiolysis and sclerosis are reported in animals receiving as little as one dose of CP (Lavin and Koss, 1971; Raymond, 1984). Similarly, sever histopathological changes in 
kidney were reported 48 hours after $\mathrm{CP}$ secondary to oxidative stress and inflammation (Hamsa and Kuttan, 2011).

On the other hand, WPI supplementation significantly improved renal pathologic picture to show normal glomeruli with WPI (300 mg/kg)-treatment. Several literature supported the notion that potent antioxidants through boosting cellular antioxidant armoury can manage and attenuate the renal damage induced by CP (Ghosh et al., 1999; Rehman et al., 2012); having GSH-boosting capacity ( $\mathrm{Xu}$ et al., 2011), WPI played the same role.

\section{CONCLUSION}

The present findings demonstrated that WPI offers ameliorative effects against CP-induced hepatorenal damage in rats via antioxidant and anti-inflammatory properties.

\section{Financial support and sponsorship: Nil.}

Conflict of Interests: There are no conflicts of interest.

\section{REFERENCES}

Abraham P, Isaac B, Ramamoorthy H, Natarajan K. Oral glutamine attenuates cyclophosphamide-induced oxidative stress in the bladder but does not prevent hemorrhagic cystitis in rats. Journal of medical toxicology : official journal of the American College of Medical Toxicology, 2011; 7: 118-124.

Ajello M, Greco R, Giansanti F, Massucci M T, Antonini G, Valenti P. Anti-invasive activity of bovine lactoferrin towards group A streptococci. Biochem Cell Biol, 2002; 80: 119-124.

Alhumaidha K A, Saleh D O, Abd El Fattah M A, El-Eraky W I, Moawad H. Cardiorenal protective effect of taurine against cyclophosphamide-induced toxicity in albino rats. Can J Physiol Pharmacol, 2015: 1-9.

Aparicio V A, Nebot E, Porres J M, Ortega F B, Heredia J M, Lopez-Jurado M, Ramirez P A. Effects of high-whey-protein intake and resistance training on renal, bone and metabolic parameters in rats. The British journal of nutrition, 2011; 105: 836-845.

Athira S, Mann B, Sharma R, Kumar R. Ameliorative potential of whey protein hydrolysate against paracetamol-induced oxidative stress. J Dairy Sci, 2013; 96: 1431-1437.

Bancroft J, Stevens A, Turner D. 1996. Theory and practice of histological techniques: Churchill Livingstone New York. the text. 766.

Benvegnu D, Barcelos R C, Boufleur N, Reckziegel P, Pase C S, Muller L G, Martins N M, Vareli C, Burger M E. Protective effects of a by-product of the pecan nut industry (Carya illinoensis) on the toxicity induced by cyclophosphamide in rats Carya illinoensis protects against cyclophosphamide-induced toxicity. Journal of environmental pathology, toxicology and oncology : official organ of the International Society for Environmental Toxicology and Cancer, 2010; 29: 185-197.

Beutler E, Duron O, Kelly B M. Improved method for the determination of blood glutathione. The Journal of laboratory and clinical medicine, 1963; 61: 882-888.

Bounous G. Whey protein concentrate (WPC) and glutathione modulation in cancer treatment. Anticancer Res, 2000; 20: 4785-4792.

Bounous G, Gervais F, Amer V, Batist G, Gold P. The influence of dietary whey protein on tissue glutathione and the diseases of aging. Clin Invest Med, 1989; 12: 343-349.
Cho K H, Hyun J H, Chang Y S, Na Y G, Shin J H, Song K H. Expression of nitric oxide synthase and aquaporin-3 in cyclophosphamide treated rat bladder. International neurourology journal, 2010; 14: 149-156.

Collins A, Duthie S, Ross M. Micronutrients and oxidative stress in the aetiology of cancer. The Proceedings of the Nutrition Society, 1994; 53: 67-75.

DeLeve L D. Cellular target of cyclophosphamide toxicity in the murine liver: role of glutathione and site of metabolic activation. Hepatology, 1996; 24: 830-837.

Dinarello C A. Proinflammatory and anti-inflammatory cytokines as mediators in the pathogenesis of septic shock. Chest, 1997; 112: 321S-329S.

Eliwa H A, El-Denshary E S, Nada S A, Elyamany M F, Omara E A, Asaaf N. Evaluation Of The Therapeutic Effect Of Whey Proteins On The Hepatotoxicity Induced By Paracetamol And Alcohol Coadministration In Rats. International Journal Of Pharmaceutical Research And Bio-Science, 2014; 3: 295-314.

Fraiser L H, Kanekal S, Kehrer J P. Cyclophosphamide toxicity. Characterising and avoiding the problem. Drugs, 1991; 42: 781-795.

Gad A S, Khadrawy Y A, El-Nekeety A A, Mohamed S R, Hassan N S, Abdel-Wahhab M A. Antioxidant activity and hepatoprotective effects of whey protein and Spirulina in rats. Nutrition, 2011; 27: 582-589.

Geng Y, Blanco F J, Cornelisson M, Lotz M. Regulation of cyclooxygenase- 2 expression in normal human articular chondrocytes. J Immunol, 1995; 155: 796-801.

Germoush M O, Mahmoud A M. Berberine mitigates cyclophosphamide-induced hepatotoxicity by modulating antioxidant status and inflammatory cytokines. J Cancer Res Clin Oncol, 2014; 140: 1103-1109.

Ghosh S, Ghosh D, Chattopadhyay S, Debnath J. Effect of ascorbic acid supplementation on liver and kidney toxicity in cyclophosphamide-treated female albino rats. The Journal of toxicological sciences, $1999 ; 24: 141-144$.

Girard B M, Malley S E, Braas K M, Waschek J A, May V, Vizzard M A. Exaggerated expression of inflammatory mediators in vasoactive intestinal polypeptide knockout (VIP-/-) mice with cyclophosphamide (CYP)-induced cystitis. J Mol Neurosci, 2008; 36: 188-199.

Habibi E, Shokrzadeh M, Chabra A, Naghshvar F, Keshavarz-Maleki R, Ahmadi A. Protective effects of Origanum vulgare ethanol extract against cyclophosphamide-induced liver toxicity in mice. Pharm Biol, 2015; 53: 10-15.

Hamsa T P, Kuttan G. Protective role of Ipomoea obscura (L.) on cyclophosphamide-induced uro- and nephrotoxicities by modulating antioxidant status and pro-inflammatory cytokine levels. Inflammopharmacology, 2011; 19: 155-167.

Hegazy R, Salama A, Mansour D, Hassan A. Renoprotective Effect of Lactoferrin against Chromium-Induced Acute Kidney Injury in Rats: Involvement of IL-18 and IGF-1 Inhibition. PLoS One, 2016; 11: e0151486.

Hessin A, Hegazy R, Hassan A, Yassin N, Kenawy S. Lactoferrin Enhanced Apoptosis and Protected Against Thioacetamide-Induced Liver Fibrosis in Rats. Open access Macedonian journal of medical sciences, 2015; 3: 195-201.

Hoffman J R, Falvo M J. Protein - Which is Best? Journal of sports science \& medicine, 2004; 3: 118-130.

Jnaneshwari S, Hemshekhar M, Santhosh M S, Sunitha K, Thushara R, Thirunavukkarasu C, Kemparaju K, Girish K S. Crocin, a dietary colorant, mitigates cyclophosphamide-induced organ toxicity by modulating antioxidant status and inflammatory cytokines. J Pharm Pharmacol, 2013; 65: 604-614. 
Jnaneshwari S, Hemshekhar M, Thushara R M, Sundaram M S, Santhosh M S, Sunitha K, Shankar R L, Kemparaju K, Girish K S. Sesamol ameliorates cyclophosphamide-induced hepatotoxicity by modulating oxidative stress and inflammatory mediators. Anticancer Agents Med Chem, 2014; 14: 975-983.

Kehrer J P, Biswal S S. The molecular effects of acrolein. Toxicol Sci, 2000; 57: 6-15.

Kent K D, Harper W J, Bomser J A. Effect of whey protein isolate on intracellular glutathione and oxidant-induced cell death in human prostate epithelial cells. Toxicol In Vitro, 2003; 17: 27-33.

Krissansen G W. Emerging health properties of whey proteins and their clinical implications. J Am Coll Nutr, 2007; 26: 713S-723S.

Lavin P, Koss L G. Effects of a single dose of cyclophosphamide on various organs in the rat. IV. Electron microscopic study of the renal tubules. Am J Pathol, 1971; 62: 169180.

Lawson M, Vasilaras A, De Vries A, Mactaggart P, Nicol D. Urological implications of cyclophosphamide and ifosfamide. Scandinavian journal of urology and nephrology, 2008; 42: 309-317.

Linares-Fernandez B E, Alfieri A B. Cyclophosphamide induced cystitis: role of nitric oxide synthase, cyclooxygenase-1 and 2, and NK(1) receptors. J Urol, 2007; 177: 1531-1536.

Lipton S A, Choi Y B, Pan Z H, Lei S Z, Chen H S, Sucher N J, Loscalzo J, Singel D J, Stamler J S. A redox-based mechanism for the neuroprotective and neurodestructive effects of nitric oxide and related nitroso-compounds. Nature, 1993; 364: 626-632.

Low P P, Rutherfurd K J, Gill H S, Cross M L. Effect of dietary whey protein concentrate on primary and secondary antibody responses in immunized BALB/c mice. Int Immunopharmacol, 2003; 3: 393-401.

$\mathrm{Lu} \mathrm{S} \mathrm{C.} \mathrm{Regulation} \mathrm{of} \mathrm{glutathione} \mathrm{synthesis.} \mathrm{Molecular}$ aspects of medicine, 2009; 30: 42-59.

Ludeman S M. The chemistry of the metabolites of cyclophosphamide. Curr Pharm Des, 1999; 5: 627-643.

Mahmoud A M. Hesperidin protects against cyclophosphamide-induced hepatotoxicity by upregulation of PPARgamma and abrogation of oxidative stress and inflammation. Can J Physiol Pharmacol, 2014; 92: 717-24.

Mansour D F, Eldenshary E-e S, Nada S A, Omara E, Ibrahim M. Therapeutic effectiveness of certain whey proteins on lipopolysaccharide-induced oxidative stress and histopathological changes in rat liver. Journal of applied sciences research, 2013; 9: 4983-4992.

Mansour D F, Nada S A, El-Denshary E S, Omara E A, Asaad G F, Abdel-Rahman R F. Milk whey proteins modulate endotoxemia-induced hepatotoxicity in rats. Int $\mathrm{J}$ Pharm Pharm Sci, 2015a; 7: 65-71.

Mansour D F, Nada S A, Eldenshary E S, Elmahmoudy B M, AbdElgayed S S. Antioxidant and Hypo-Ammonemic Activities of Alpha-Lactalbumin and Vitamin $\mathrm{C}$ in Thioacetamide-Induced Liver and Brain Damage in Rats. Journal of Applied Pharmaceutical Science, 2015b; 5: 072-081.

Martin W F, Armstrong L E, Rodriguez N R. Dietary protein intake and renal function. Nutrition \& metabolism, 2005; 2: 25.

Miranda K M, Espey M G, Wink D A. A Rapid, Simple Spectrophotometric Method for Simultaneous Detection of Nitrate and Nitrite. Nitric Oxide, 2001; 5: 62-71.

Mitchell C J, McGregor R A, D'Souza R F, Thorstensen E B, Markworth J F, Fanning A C, Poppitt S D, Cameron-Smith D. Consumption of Milk Protein or Whey Protein Results in a Similar Increase in Muscle Protein Synthesis in Middle Aged Men. Nutrients, 2015; 7: 8685-8699.
Morr C V, Ha E Y. Whey protein concentrates and isolates: processing and functional properties. Crit Rev Food Sci Nutr, 1993; 33:431-76.

Nada S A, Hassan N F, Eldenshary E S, Abdel Reheem G, Hassan A H M. Whey protein products and their combination with 1methionine prevent liver fibrosis incidence in thioacetamide-toxicated rats. IOSR Journal Of Pharmacy, 2015; 5: 19-28.

Oter S, Korkmaz A, Oztas E, Yildirim I, Topal T, Bilgic H. Inducible nitric oxide synthase inhibition in cyclophosphamide induced hemorrhagic cystitis in rats. Urological research, 2004; 32: 185-189.

Oyagbemi A A, Omobowale O T, Asenuga E R, Akinleye A S, Ogunsanwo R O, Saba A B. Cyclophosphamide-induced Hepatotoxicity in Wistar Rats: The Modulatory Role of Gallic Acid as a Hepatoprotective and Chemopreventive Phytochemical. International journal of preventive medicine, 2016; 7: 51.

Pena-Ramos E A, Xiong Y L. Antioxidative activity of whey protein hydrolysates in a liposomal system. J Dairy Sci, 2001; 84:2577-83.

Peng X, Xiong Y L, Kong B. Antioxidant activity of peptide fractions from whey protein hydrolysates as measured by electron spin resonance. Food Chem., 2009; 113: 196-201.

Pennings B, Boirie Y, Senden J M, Gijsen A P, Kuipers H, van Loon $\mathrm{L}$ J. Whey protein stimulates postprandial muscle protein accretion more effectively than do casein and casein hydrolysate in older men. Am J Clin Nutr, 2011; 93: 997-1005.

Raymond J R. Nephrotoxicities of antineoplastic and immunosuppressive agents. Current problems in cancer, 1984; 8: 1-32.

Rehman M U, Tahir M, Ali F, Qamar W, Lateef A, Khan R, Quaiyoom A, Oday O H, Sultana S. Cyclophosphamide-induced nephrotoxicity, genotoxicity, and damage in kidney genomic DNA of Swiss albino mice: the protective effect of Ellagic acid. Mol Cell Biochem, 2012; 365: 119-127.

Reitman S, Frankel S. A colorimetric method for the determination of serum glutamic oxalacetic and glutamic pyruvic transaminases. American journal of clinical pathology, 1957; 28: 5663.

Salama A A A, Eldenshary E E-D S, Nada S A, Mansour H M, Asaaf N, Shaffie N M. Effect of whey protein against fluvastatin and carbon tetrachloride-induced hepatotoxicity in rats Der Pharmacia Lettre, 2015; 11: 9-23.

Saleh D O, Mansour D F. Ovario-protective effects of genistein against cyclophosphamide toxicity in rats: Role of antimullerian hormone and oestradiol. Eur J Pharmacol, 2016; 789: 163171.

Samad T A, Moore K A, Sapirstein A, Billet S, Allchorne A, Poole S, Bonventre $\mathrm{J} \mathrm{V}$, Woolf $\mathrm{C} \mathrm{J}$. Interleukin-1beta-mediated induction of Cox-2 in the CNS contributes to inflammatory pain hypersensitivity. Nature, 2001; 410: 471-475.

Sayed-Ahmed M M. Progression of cyclophosphamideinduced acute renal metabolic damage in carnitine-depleted rat model. Clinical and experimental nephrology, 2010; 14: 418-426.

Selvakumar E, Prahalathan C, Mythili Y, Varalakshmi P. Mitigation of oxidative stress in cyclophosphamide-challenged hepatic tissue by DL-alpha-lipoic acid. Mol Cell Biochem, 2005; 272: 179185 .

Senthilkumar S, Devaki T, Manohar B M, Babu M S. Effect of squalene on cyclophosphamide-induced toxicity. Clin Chim Acta, 2006; 364: 335-342.

Tsai W Y, Chang W H, Chen C H, Lu F J. Enchancing effect of patented whey protein isolate (Immunocal) on cytotoxicity of an anticancer drug. Nutr Cancer, 2000; 38: 200-208.

Tseng Y M, Lin S K, Hsiao J K, Chen I J, Lee J H, Wu S H, Tsai L Y. Whey protein concentrate promotes the production of 
glutathione $(\mathrm{GSH})$ by GSH reductase in the $\mathrm{PC} 12$ cell line after acute ethanol exposure. Food Chem Toxicol, 2006; 44: 574-578.

Uchiyama M, Mihara M. Determination of malonaldehyde precursor in tissues by thiobarbituric acid test. Analytical biochemistry, 1978; 86: 271-278.

Watanabe A, Okada K, Shimizu Y, Wakabayashi H, Higuchi K, Niiya K, Kuwabara Y, Yasuyama T, Ito H, Tsukishiro T, Kondoh Y, Emi N, Kohri H. Nutritional therapy of chronic hepatitis by whey protein (non-heated). J Med, 2000; 31: 283-302.

Weinberg E D. The role of iron in cancer. Eur J Cancer Prev, 1996; 5: 19-36.

Xu R, Liu N, Xu X, Kong B. Antioxidative effects of whey protein on peroxide-induced cytotoxicity. J Dairy Sci, 2011; 94: 373946.

Yamaguchi M, Matsuura M, Kobayashi K, Sasaki H, Yajima T, Kuwata T. Lactoferrin protects against development of hepatitis caused by sensitization of Kupffer cells by lipopolysaccharide. Clin Diagn Lab Immunol, 2001; 8: 1234-1239.

Yoo Y C, Watanabe S, Watanabe R, Hata K, Shimazaki K, Azuma I. Bovine lactoferrin and Lactoferricin inhibit tumor metastasis in mice. Adv Exp Med Biol, 1998; 443: 285-291.
Zarei M, Shivanandappa T. Amelioration of cyclophosphamide-induced hepatotoxicity by the root extract of Decalepis hamiltonii in mice. Food Chem Toxicol, 2013; 57: 179-184.

Zhu H, Long M H, Wu J, Wang M M, Li X Y, Shen H, Xu J D, Zhou L, Fang Z J, Luo Y, Li S L. Ginseng alleviates cyclophosphamide-induced hepatotoxicity via reversing disordered homeostasis of glutathione and bile acid. Scientific reports, 2015; 5: 17536.

\section{How to cite this article:}

Mansour DF, Salama AA, Hegazy RR, Omara EA, Nada SA. Whey protein isolate protects against cyclophosphamide-induced acute liver and kidney damage in rats. J App Pharm Sci, 2017; 7 (06): 111-120. 